\title{
ビルピット内物質の成分分析と浸漬試験によるライニング材劣化要因の特定 ビルピット用ライニング材の厨房排水による劣化機構に関する研究 その 1 IDENTIFICATION OF DEGRADATION FACTORS OF LINING MATERIAL BY COMPONENT ANALYSIS OF SUBSTANCES IN PITS AND IMMERSION EXPERIMENT
}

The mechanism of degradation due to kitchen drainage of lining material for building pits Part1

\author{
吉田真 悟*, 長谷川 完**, 高橋 拡*** \\ Shingo YOSHIDA, Tamotsu HASEGAWA and Hiromu TAKAHASHI
}

\begin{abstract}
In order to elucidate the mechanism of degradation due to kitchen drainage of epoxy resin used as a lining material for building pits, several investigations and experiments were conducted. The drainage water and the floating substance from the pit of building A and B were sampled and analyzed. Trace amounts of short-chain fatty acids were detected from the drainage water, whereas trace amounts of short-chain fatty acids and large amounts of long-chain fatty acids were detected from the floating substances. Experiments to immerse epoxy resin test pieces in the drainage water, the floating substances, the aqueous solution of short-chain fatty acids, and the large amounts of long-chain fatty acids were carried out. Both test pieces immersed in the floating substances and long-chain fatty acids became expanded by swelling. From the results above, it should be concluded that long-chain fatty acids contained in the floating substances are the factors affecting the degradation of epoxy resin as a lining material in pits.
\end{abstract}

Keywords : Lining Material, Kitchen Drainage, Pit, Scum, Organic Acid, Epoxy Resin ライニング材, 㕌房排水, ビルピット, スカム, 有機酸, エポキシ

\section{1.はじめに}

オフィスビルやショッピングモール，ホテル等の建物には，レス トラン街が設置されることが多く，これらの厨房からの排水量が $50 \mathrm{~m}^{3} /$ 日を超える建物では, 排水中に含まれる有機物を低減するため, 厨房除害施設の設置が義務付けられている。厨房除害施設に付随し, 㕌房からの排水を一時的に貯留する水槽は, 敷地の関係から建物地 下に設置されることが多く，一般的にビルピットと呼ばれている。

ビルピットで起こる腐食あるいは劣化についての研究は少ないが, 下水道施設等と同じくコンクリートの硫酸腐食が起こることが知ら れている ${ }^{4,5)}$ 。下水道施設等におけるコンクリート硫酸腐食の機構に ついては，これまでに多くの研究があり，排水中の硫黄分と有機物 から嫌気性細菌により硫化水素が発生し，さらに排水中から気相部 に放出された硫化水素が好気性細菌の関与により酸化し, 下水道管 等の天井面結露水と結びついて局所的に濃度の高い硫酸が発生し, この硫酸とコンクリートが反応して石膏を生じることで，コンクリ 一トの腐食が進むことが報告されている ${ }^{6}$ 。これらの研究成果をも とに日本下水道事業団の規格 ${ }^{7}$ が設定され, ビルピットにおいても, この規格に準拠して, コンクリート製の躯体を硫酸腐食から保護す る目的で耐薬品性に優れるエポキシ樹脂やビニルエステル樹脂がラ
イニング材として施工されることが多くなっている。

このような耐薬品性の高い仕様設定が行われているにも関わらず, 有機物量が比較的多い排水が流れ込むビルピットにおいて, エポキ シ樹脂製のライニング材が劣化する事例が見られた。このような事 例の原因として, 系平らは, ビルピットの排水中の有機物成分が分 解することによって生成した有機脂肪酸, 特に高級脂肪酸の影響を 指摘している ${ }^{8)}$ 。一方, 久保内らは, ライニング材として用いられ るエポキシ樹脂は，低級脂肪酸である酢酸により劣化することを報 告している ${ }^{9)}$ 。最近では, ビルピット用のライニング材として, 耐 有機酸性を謳う製品も登場してきており，その劣化対策が進んでき ているものの ${ }^{10)}$, ビルピット内に存在する有機酸の種類や存在量を 踏まえた体系的な検討はされておらず，その劣化機構はいまだ明ら かになっているとは言い難い。

本報では，このような現状を踏まえ，ビルピット内から採取した 排水・浮遊物の成分分析により, ビルピット内における有機酸, 特 に脂肪酸の存在状況を把握し, その存在状況を踏まえた上で, いく つかの試薬等を使用したライニング材の浸漬試験を行うことによっ て, ビルピット内のライニング材の劣化機構について考察を行った 結果を報告する。

\footnotetext{
本論文は, 文献 ${ }^{1 \sim 3}$ に発表した内容を修正, 加筆したものである。

* 竹中工務店技術研究所 研究主任.工修

** 竹中工務店技術研究所 主任研究員

*** 竹中工務店技術研究所 主任研究員·工修
}

Associate Chief Researcher, Takenaka Research \& Development Institute, M. Eng.

Chief Researcher, Takenaka Research \& Development Institute

Chief Researcher, Takenaka Research \& Development Institute, M. Eng. 


\section{2. 現地調査とサンプル採取}

ビルピット内の状況を把握するため，2つの建物 $\mathrm{A}, \mathrm{B}$ のビルピ ットにて現地調査とサンプル採取を実施した。建物 $\mathrm{A}$ はショッピン グモール，建物 B はホテルでいずれもレストランを有しており，こ れら厨房からの排水が直接流れ込む水槽（排水処理前）にて調査と サンプル採取を行った。排水はいずれの建物においても褐色に濁り， 固形状の浮遊物が浮かんでいた。浮遊物の状態は, 水槽内の曝気装 置の有無により状況が異なっていた。曝気装置のない建物 A の水槽 では, 喫水面に泥状の浮遊物（Scum, 以下「SC」とする）が存在し, 喫水面付近で浮遊物とライニング材が直接接触し, 浮遊物のライニ ング材表面への付着が見られた。ライニング材は喫水面付近で割れ てめくれあがり，コンクリート躯体が露出していた。曝気装置のあ る建物 B の水槽では，球状の浮遊物（Oil ball, 以下「OB」とする） が喫水面に存在するものの, ライニング材表面への付着が少なく, ライニング材の劣化も見られなかった。建物 A では排水と $\mathrm{SC}$ を, 建物 B では排水と OB を, それぞれ柄杓や網でボトルに採取し, 腐 敗が進まないよう冷蔵保存して各種分析に供した。

\section{3. 排水の水質分析}

\section{1 分析方法}

建物 $\mathrm{A}, \mathrm{B}$ の排水について, 通常行われる水質分析での位置付け を把握するため, 一般排水の水質分析項目のうち有機物量に関係す る項目である BOD (生物化学的酸素要求量), $\mathrm{SS}$ (浮遊物質量), $\mathrm{n}$ -HEX (ノルマルヘキサン抽出物質含有量, 動植物油脂類)について, JIS K 0102, 昭和 46 年環境庁告示第 59 号付表 9 および昭和 49 年環 境庁告示第 64 号付表 4 に従い，分析を行った。

\section{2 分析結果}

水質分析の結果を Table1 に示寸。BOD, SS, n-HEX の環境省 令一律排水基準は，それぞれ $160 ， 200 ， 30 \mathrm{mg} / \mathrm{L}$ であり，排水処 理前では建物 A, B ともにこの值を上回っていて, 多くの有機物が 含まれていることが把握された。特に, 曝気装置のない建物 $\mathrm{A}$ の排 水の方が各項目ともに值が大きく, 有機物量が多いことがわかった。

\begin{tabular}{|c|c|c|c|c|}
\hline Building & $\begin{array}{c}\text { Aeration } \\
\text { system }\end{array}$ & $\begin{array}{l}\text { BOD } \\
\mathrm{mg} / \mathrm{L}\end{array}$ & $\begin{array}{c}\mathrm{SS} \\
\mathrm{mg} / \mathrm{L}\end{array}$ & $\begin{array}{c}\text { n-HEX } \\
\mathrm{mg} / \mathrm{L}\end{array}$ \\
\hline A & - & 2420 & 3100 & 1970 \\
\hline B & 0 & 390 & 220 & 83 \\
\hline
\end{tabular}

\section{4. 有機酸分析}

\section{1 分析方法}

建物 $\mathrm{A}$ の排水と $\mathrm{SC}$, 建物 $\mathrm{B}$ の排水と $\mathrm{OB}$ に低級脂肪酸を含む有 機酸がどの程度存在するかを把握するため, 有機酸分析を実施した。 排水はそのまま, SC と OB は弱アルカリ水で振とう抽出した後, 濾 過を行い，有機酸分析計（昭和電工製：Shodex OA）にて測定を行 った。主な分析条件は, カラム: 昭和電工製 Shodex Ionpak KC-810P, $\mathrm{KC}-811$, カラム温度 : $50^{\circ} \mathrm{C}$, 溶離液 : $2 \mathrm{mM}$ 過塩素酸/純水, 溶離液 流量 $1.0 \mathrm{~mL} / \mathrm{min}$., 発色液 : $10 \% \mathrm{ST}-3-\mathrm{R}(0.6 \mathrm{~mL} / \mathrm{min}$.), 試料注入量 : $100 \mu \mathrm{L}$ とした。有機酸成分を試薬により選択的に発色させ， $430 \mathrm{~nm}$
の吸光度で検出した。

\section{2 分析結果}

有機酸分析の結果を Table2 に示す。建物 A の排水および SC から はリン酸と炭素数 2 から 5 までの直鎖低級脂肪酸, イソ吉草酸が検 出された。建物 $\mathrm{B}$ の排水からはリン酸と酢酸, OB からは乳酸と炭 素数 1 から 5 までの直鎖低級脂肪酸が検出された。建物 $\mathrm{A}$ と B の排 水の比較では, 水質分析で有機物量の多かった建物 $\mathrm{A} の$ 排水の方が, 低級脂肪酸含有量が多い結果となった。一方，排水と SC（もしくは OB）を比較すると，排水よりも SC（もしくは OB）に含まれる低級 脂肪酸含有量が多い結果であった。排水中の低級脂肪酸の総量は最 大で $100 \mu \mathrm{g} / \mathrm{mL}$ （排水の比重を 1 とすれば $0.01 \mathrm{wt} \%$ に相当）程度であ り，浮遊物中の低級脂肪酸総量は，振とう抽出により低級脂肪酸が すべて抽出されたと仮定すると $1000 \mu \mathrm{g} / \mathrm{g}(0.1 \mathrm{wt} \%)$ 程度であること が把握された。 SC と $\mathrm{OB}$ の比較では, 有機酸の構成比率が異なり, $\mathrm{OB}$ の方が炭素数の小さい脂肪酸が多い傾向が見られた。

Table2 Result of organic acid analysis

\begin{tabular}{ccccc}
\hline \multirow{2}{*}{ Organic } & \multicolumn{2}{c}{ Building A } & \multicolumn{2}{c}{ Building B } \\
\cline { 2 - 5 } acid & Drainage & Scum & Drainage & Oil ball \\
& water & $(\mathrm{SC})$ & water & $(\mathrm{OB})$ \\
\cline { 2 - 5 } & $\mu \mathrm{g} / \mathrm{mL}$ & $\mu \mathrm{g} / \mathrm{g}$ & $\mu \mathrm{g} / \mathrm{mL}$ & $\mu \mathrm{g} / \mathrm{g}$ \\
\hline Oxalic acid & $<1$ & $<20$ & $<1$ & $<20$ \\
Phosphoric acid & 2.5 & 56 & 5.7 & $<20$ \\
Citric acid & $<1$ & $<20$ & $<1$ & $<20$ \\
Lactic acid & $<1$ & $<20$ & $<1$ & 200 \\
Formic acid & $<1$ & 45 & $<1$ & 30 \\
Acetic acid & 55 & 80 & 8.4 & 660 \\
Propionic acid & 34 & 160 & $<1$ & 130 \\
Isobutyric acid & $<1$ & $<20$ & $<1$ & $<20$ \\
n-Butyric acid & 11 & 260 & $<1$ & 210 \\
Isovaleric acid & 6.2 & 180 & $<1$ & $<20$ \\
n-Valeric acid & 7.7 & 350 & $<1$ & 50 \\
\hline
\end{tabular}

\section{5. 浮遊物の主成分分析 \\ 5. 1 分析方法 \\ (1) 分析の位置付け}

4 章で有機酸成分の分析を行ったが，この手法は分子量の小さい 水溶性の有機酸成分を測定する方法であった。本章では，比較的分 子量の大きい有機物成分を定性することを目的として，熱重量分析 と熱分解ガスクロマトグラフィー質量分析を行った。

\section{(2) 前処理}

4 章で分析に用いたものと同じ $\mathrm{SC}, \mathrm{OB}$ それぞれを $10 \mathrm{~g}$ 程度ガラ スシャーレに取り，スパチュラを用いて細かく砕きながら，試料全 体が均一に混ざるようによく混練し，分析に供した。

\section{（3）熱重量分析}

$\mathrm{SC}, \mathrm{OB}$ それぞれを $5 \mathrm{mg}$ 程度採取し, Rigaku製: Thermo plus TG8120 を用いて熱重量分析（以下，「TG 分析」とする）を行った。主な分 析条件は, $\mathrm{N}_{2}$ 雰囲気下, 昇温速度: $10^{\circ} \mathrm{C} / \mathrm{min}$., 測定温度 : 常温 $~ 600^{\circ} \mathrm{C}$ とした。 


\section{（4）熱分解ガスクロマトグラフィー質量分析}

$\mathrm{SC}, \mathrm{OB}$ それぞれを $500 \mu \mathrm{g}$ 程度採取し, 熱分解ガスクロマトグラ フィー質量分析装置（以下，「Py-GC/MS 分析」とする）にて主成分 分析を行った。装置の構成は, 熱分解装置部 (Py) : Frontier Lob 製 PY-2020iD，ガスクロマトグラフィー部（GC）：Agilent 製 7890A, 質量分析部（MS）: 日本電子製 JMS-Q1000GC Mk II であった。ダブ ルショット法を用い, $300^{\circ} \mathrm{C} 2 \mathrm{~min}$. 試料加熱, $500^{\circ} \mathrm{C} 2 \mathrm{~min}$. 試料加熱の 2 段階で GC/MS にガスを導入して成分分析を行った。

主な GC 条件は，カラム：Frontier Lob 製 Ultra ALLOY+-5（微極 性), 温度条件： $40^{\circ} \mathrm{C} 2 \mathrm{~min}$. 保持 $10^{\circ} \mathrm{C} / \mathrm{min}$. 昇温 $320^{\circ} \mathrm{C} 30 \mathrm{~min}$. 保持, カラム流量： $1 \mathrm{~mL} / \mathrm{min}$., スプリット比: 10〜100 (サンプルによる), 注入口温度 : $320^{\circ} \mathrm{C}$ とした。主な $\mathrm{MS}$ 条件は, GCインターフェイス 温度 : $320^{\circ} \mathrm{C}$, イオン源温度 : $320^{\circ} \mathrm{C}$, 設定質量数 : $29-500$, サイク

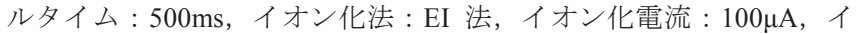
オン化エネルギー : $70 \mathrm{eV}$, 検出器電圧 : $-1000 \mathrm{~V}$ とた。

\section{2 分析結果}

\section{(1) 熱重量分析}

$\mathrm{SC}, \mathrm{OB}$ の TG 分析結果を Fig.1 に示す。なお, 図中灰色の補助線 は, 次項の Py-GC/MS 分析の設定温度である。

$\mathrm{SC}$ については, 常温から $100^{\circ} \mathrm{C}$ までに $25 \%$ 程度, $200^{\circ} \mathrm{C}$ から $290^{\circ} \mathrm{C}$ にかけて $40 \%$ 程度, $290^{\circ} \mathrm{C}$ から $360^{\circ} \mathrm{C}$ にかけて $10 \%$ 程度の重量減少が 見られ，25\%程度が残渣となった。

OB については, 常温から $100^{\circ} \mathrm{C}$ までに $5 \%$ 程度, $200^{\circ} \mathrm{C}$ から $300^{\circ} \mathrm{C}$ にかけて $30 \%$ 程度, $300^{\circ} \mathrm{C}$ から $360^{\circ} \mathrm{C}$ にかけて $10 \%$ 程度, $360^{\circ} \mathrm{C}$ から $440^{\circ} \mathrm{C}$ にかけて $10 \%$ 程度, $440^{\circ} \mathrm{C}$ から $500^{\circ} \mathrm{C}$ にかけて $17 \%$ 程度の重量 減少が見られ，28\%程度が残椬となった。

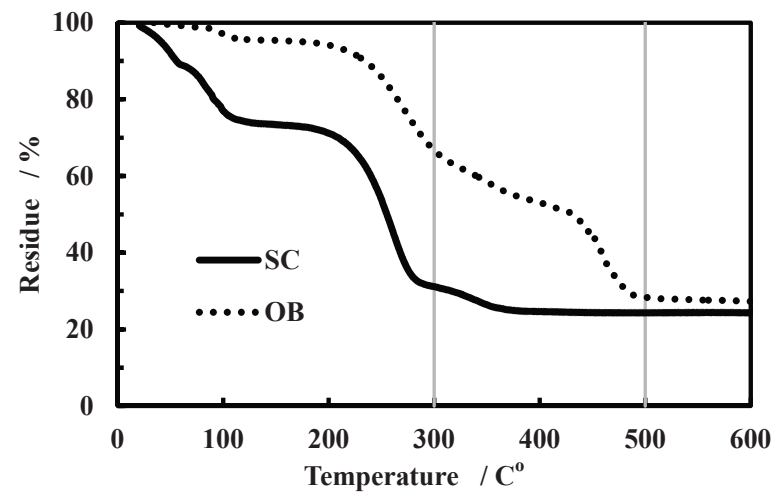

Fig.1 Thermal gravity analysis

\section{（2）熱分解ガスクロマトグラフィー質量分析}

$300^{\circ} \mathrm{C}$ で加熱した SC のトータルイオンクロマトグラム（TIC）を Fig.2 に, OB の TIC を Fig. 3 に, $300^{\circ} \mathrm{C}$ 加熱後の残分を $500^{\circ} \mathrm{C}$ で加熱 した SC の TIC を Fig.4に, OB の TIC を Fig.5 に, Fig.2〜 5 中の主 要なピークのうち MS スペクトルのライブラリ検索（Nist， Willy を使用）により定性できた成分一覧を Table3 に示す。

$300^{\circ} \mathrm{C}$ で加熱した SC の TIC（Fig.2）では，炭素数 12 のラウリン 酸, 炭素数 14 のミリスチン酸, 炭素数 16 のパルミチン酸, 炭素数 18 のステアリン酸, 炭素数 18 の不飽和脂肪酸であるオレイン酸の ピークが確認された。 $300^{\circ} \mathrm{C}$ で加熱した OB の TIC（Fig.3）では, SC
と同じ脂肪酸のピークが確認された。

$300^{\circ} \mathrm{C}$ 加熱後の残分を $500^{\circ} \mathrm{C}$ で加熱した SC の TIC（Fig.4）では, パルミチン酸, オレイン酸に加えて, コレステロール類, スチグマ ステロール類のピークが確認された。一方， $300^{\circ} \mathrm{C}$ 加熱後の残分を $500^{\circ} \mathrm{C}$ で加熱した OB の TIC（Fig.5）では，パルミチン酸，オレイン 酸に加えて,ケトン基もしくはエポキシ基を持つピークが複数確認 された。

\section{3 考察}

前節の結果より， $\mathrm{SC} ， \mathrm{OB}$ の主成分について考える。 $\mathrm{SC}$ と $\mathrm{OB}$ の $\mathrm{TG}$ 分析にて重量変化が最も大きかった $200^{\circ} \mathrm{Cから} 290^{\circ} \mathrm{C}$ の成分は, $300^{\circ} \mathrm{C}$ における TIC で確認された炭素数 $12 \sim 18$ の高級脂肪酸類であ り, その含有量は $\mathrm{TG}$ 分析の $200^{\circ} \mathrm{C}$ から $290^{\circ} \mathrm{C}$ の重量減少量から推定 すると， SC においては $35 \mathrm{wt} \%$ 以上，OB においても $20 \mathrm{wt} \%$ 以上であ る。 $\mathrm{SC}$ の $\mathrm{TG}$ 分析にて $390^{\circ} \mathrm{C}$ から $360^{\circ} \mathrm{C}$ で減少している成分は, $500^{\circ} \mathrm{C}$

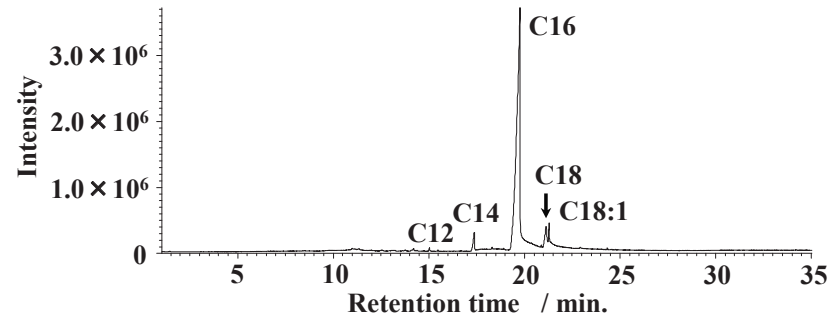

Fig.2 Total ion cromatogram $\left(\mathrm{SC}, 300 \mathrm{C}^{\circ}\right)$

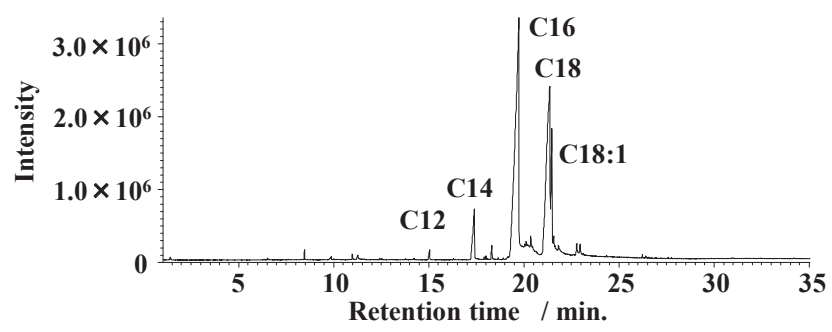

Fig.3 Total ion cromatogram $\left(\mathrm{OB}, 300 \mathrm{C}^{\circ}\right)$

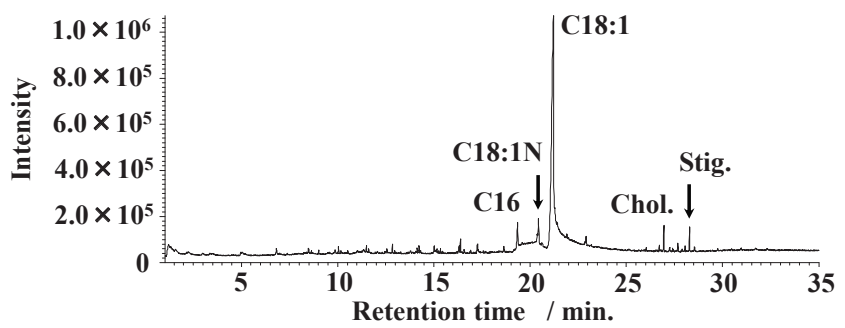

Fig.4 Total ion cromatogram (SC, 500 $\left.{ }^{\circ}\right)$

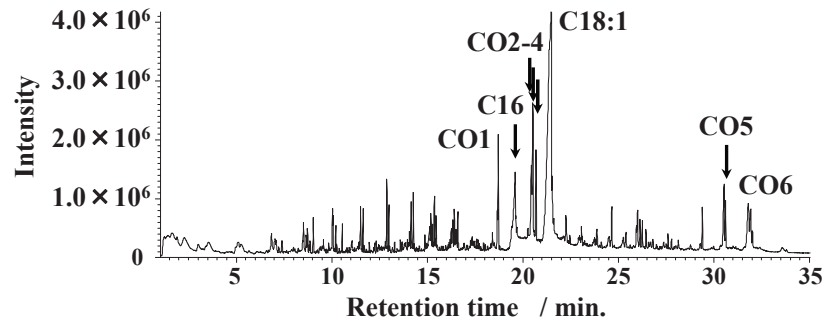

Fig.5 Total ion cromatogram (OB, $\left.500 \mathrm{C}^{\circ}\right)$ 
Table3 Qualitative analysis

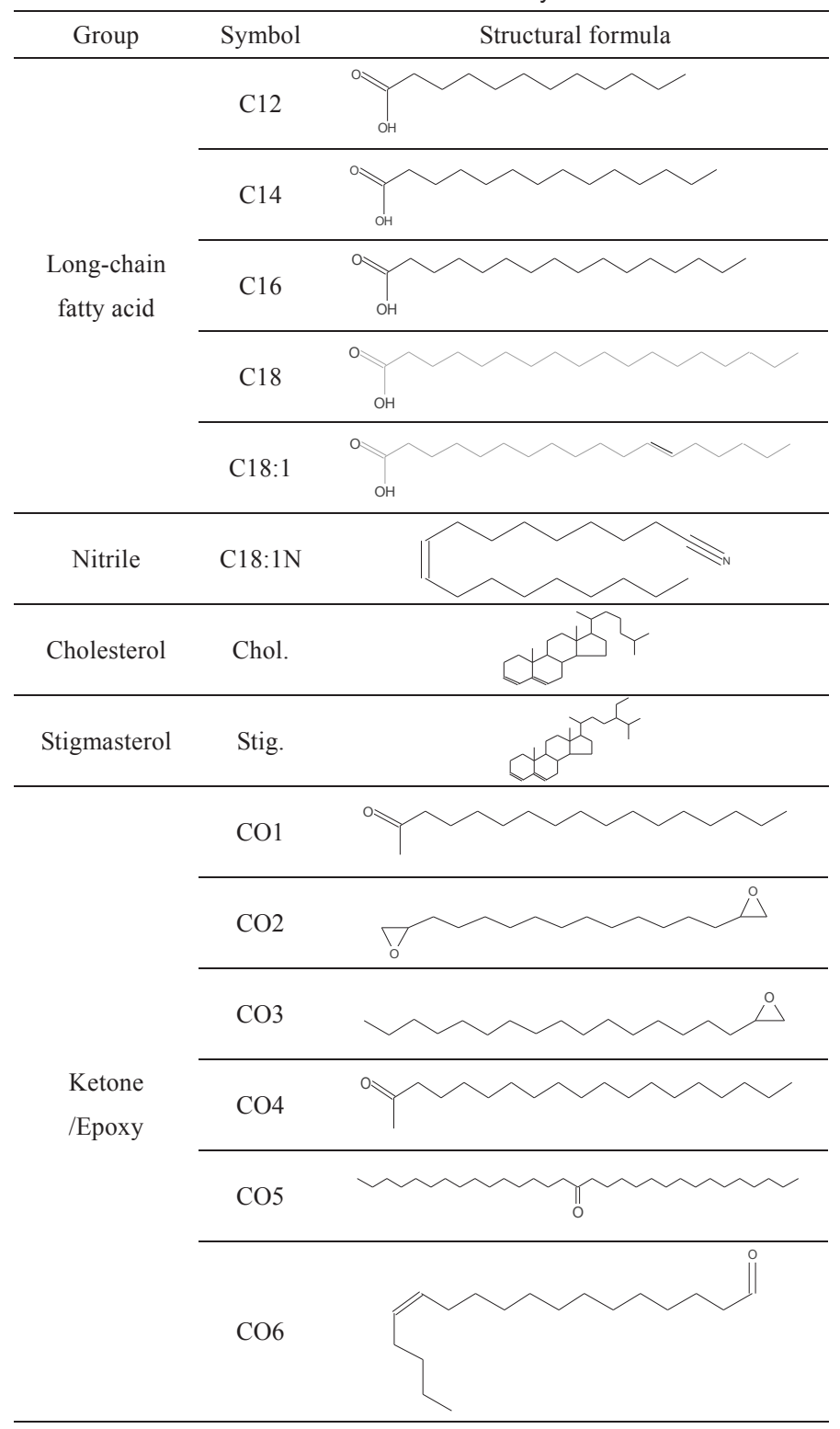

における TIC で確認されたコレステロール類等, $\mathrm{OB}$ の $\mathrm{TG}$ 分析に て $360^{\circ} \mathrm{C}$ か $440^{\circ} \mathrm{C}, 440^{\circ} \mathrm{C}$ から $500^{\circ} \mathrm{C}$ で減少している成分は, $500^{\circ} \mathrm{C}$ における TICで確認されたケトン類等の高分子量成分が含まれてい ると考えられる。

厨房からの排水は, 今回調査対象としているビルピットに流入す る前に，厨房内に設置されたグリーストラップと呼ばれる装置で油 水分離されるが ${ }^{11)}$, グリーストラップの堆積物の成分についても, 脂質の成分割合が大きく, その種類はパルミチン酸（C16）やオレ イン酸（C18:1），リノール酸が多いことが報告されている ${ }^{12)}$ 。今回 調査対象としているビルピットにおいても, グリーストラップの堆 積物と同様に，グリセリンと高級脂肪酸で構成される食用油がリパ 一ゼ等により加水分解し, 非水溶性であるために遊離して浮遊物 （SC，OB）となったものと考えられる。また， OB の構成成分は， $\mathrm{SC}$ に比べてケトン類等の酸化物が多かったが, これは排水槽内の曝 気により，油脂類が酸化して生成したものと推定される。

\section{6. 排水と浮遊物への浸漬・接触試験 \\ 6. 1 試験方法}

排水と浮遊物について, どちらがよりライニング材を劣化させる のかを確認することを目的として，排水と浮遊物（SC， OB）への 浸漬・接触試験を実施した。

ライニング材は, 日本下水道事業団の規格 $\mathrm{D}$ 種に適合した汎用的 なエポキシ樹脂系ライニング材を成型して $20^{\circ} \mathrm{C} 60 \%$ の環境下で 1 週 間養生したものを用いた。排水に浸漬させる試験片は， $60 \times 25 \times$ $1.5 \mathrm{~mm}$ の短冊状とした。 $\mathrm{SC}, \mathrm{OB}$ に接触させる試験片は, 泥状の浮 遊物の中に安定して接触させるために，やや大きい $80 \times 50 \times 1.5 \mathrm{~mm}$ の寸法とした。試験片数は, 各水準 1 体ずつとした。

排水は 3 章と 4 章の分析結果から有機物量と有機酸成分がともに 多かった建物 $\mathrm{A}$ のものを使用した（以下「DW」とする）。SC と OB については 4 章で主成分分析に用いたものと同じものを使用した。

直径 $90 \mathrm{~mm}$ の蓋付きのガラス瓶の中に, 排水 $300 \mathrm{~mL}$, もしくは SC, OB $250 \mathrm{~g}$ を入れ, 排水については試験片の全部が埋まるように, $\mathrm{SC}$, $\mathrm{OB}$ については試験片の半分程度が隠れるように泥状の $\mathrm{SC}, \mathrm{OB}$ の 中に試験片を半分程度差し込んで接触した。試験状況をPhoto1, 2 に示す。 $20^{\circ} \mathrm{C}$ の室内環境中に静置し, 期間 1， 4， 7， 14，21，28 日のタイミングでライニング材を取り出し, 重量測定と外観観察を 行い評価した。SC はそのまま, OB は前処理としてスプーンで細か く砕いて使用した。重量測定は, 試験片を純水で洗浄して付着物を 除去し, 清浄なウエスで拭き取り後に行った。初期重量に対する変 化量を初期重量で除し重量変化率を求めた。 SC と OB に接触したラ イニング材は, 接触範囲の重量を接触面積から推定し初期重量とし て用いた。

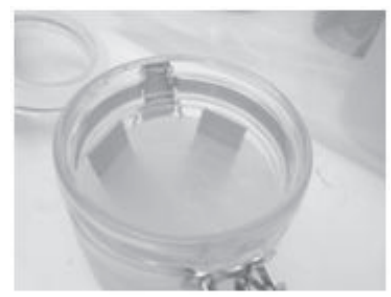

Photo1 The situation of immersion test in DW

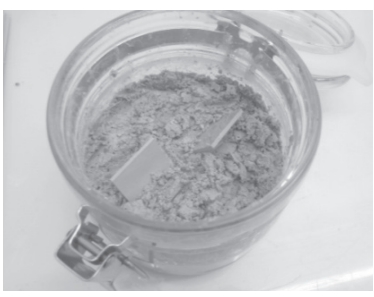

Photo2 The situation of contact test in $\mathrm{OB}$

\section{2 試験結果}

浸漬・接触試験結果を Fig.6 に示す。排水に浸漬した試験片は 28 日間の浸漬によって $1 \%$ 以下の重量増加であったのに対し, SC や $\mathrm{OB}$ への接触では $10 \%$ 以上重量が増加した。外観についても, 排水 に浸漬した試験片は, 浸漬していない試験片と比較してほとんど変 化がなかったのに対し， SC や $\mathrm{OB} に$ 接触した試験片は，接触部分に $\mathrm{SC}$ やB が付着し，軟化膨潤して大きく変形していた。排水に 28 日間浸漬した試験片の様子をPhoto3に, OB に28 日間浸漬した試験 片の様子をPhoto4 に示す。なお，写真中左側の試験片が排水もしく は $\mathrm{OB}$ への浸漬・接触品, 右側の試験片が比較用の未浸漬・未接触 品である。 


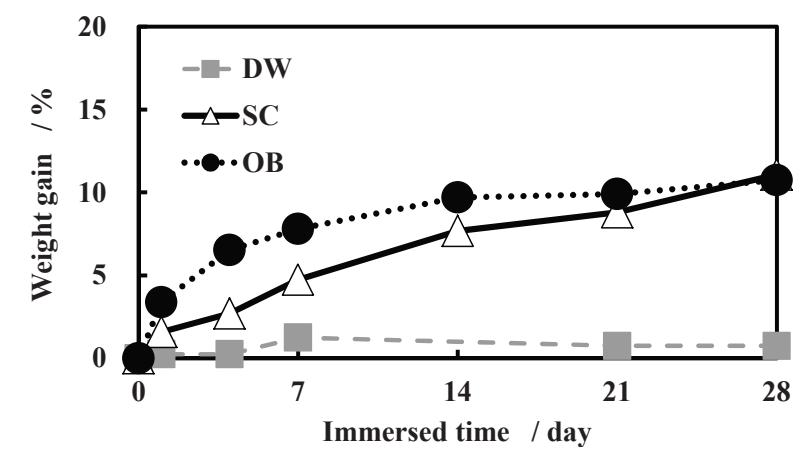

Fig.6 Weight gain of lining material

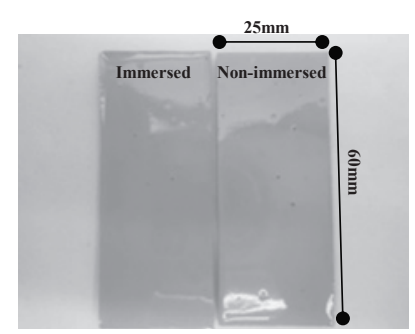

Photo3 Test piece immersed in DW (28 days)

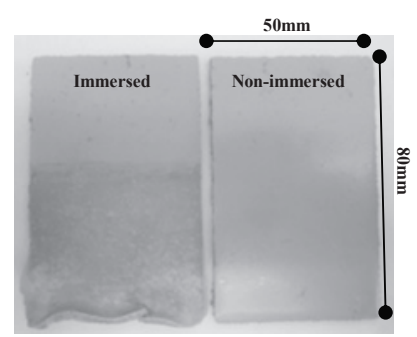

Photo4 Test piece contacted in OB (28 days)

\section{3 考察}

ライニング材を排水と浮遊物に 28 日浸漬・接触した結果, 排水に 浸漬した試験片はほとんど劣化せず, 浮遊物（SC, OB）に接触し た試験片は著しく劣化する結果となった。今回の試験は各水準の試 験片数 1 体の結果であり, さらに浮遊物への接触試験は, 試験片と 浮遊物の接触状況によって試験片の劣化程度が変化するバラつきの 大きい試験方法である。したがって $\mathrm{SC}, \mathrm{OB}$ のどちらがライニング 材をより劣化させるかは判断できない。一方で, 排水への浸漬と浮 遊物一の接触について, 試験片の寸法や浸漬（接触）面積等試験条 件の違いがあり単純な結果比較はできないが，ライニング材の重量 変化率や外観変化の大きな違いに着目すると, 排水一の浸漬に比べ て浮遊物（SC， OB）への接触の方が，ライニング材をより劣化さ せることは明らかであると言える。

5 章までの分析により, ビルピット内に存在する排水には, 水の 中に総量で $0.01 \mathrm{wt} \%$ 程度の低級脂肪酸を含む有機酸が含まれ, 浮遊 物（SC, OB）には，泥状の固形分のうち $20 \mathrm{wt} \%$ 以上が高級脂肪酸 (ミリスチン酸, パルミチン酸, ステアリン酸, オレイン酸) で, そ の中に総量で $0.1 \mathrm{wt} \%$ 程度の低級脂肪酸が含まれることがわかって いる。これらの結果から, ビルピット内においてライニング材を劣 化させる主な要因は, 排水中に微量に含まれる低級脂肪酸の影響で はなく, 喫水面の浮遊物の付着による低級脂肪酸もしくは高級脂肪 酸の影響である可能性が高いと考えられる。

\section{7. 低級脂肪酸・高級脂肪酸への浸漬試験}

\section{1 試験方法}

\section{(1) 試験の位置付け}

6 章の結果から, ビルピット内のライニング材を劣化させる主な 要因として, 排水からの影響よりも浮遊物からの影響によることが 確認できたが, 浮遊物中の成分としては, 低級脂肪酸と高級脂肪酸
が両方含まれており，どちらの影響がより大きいかを区別すること ができなかった。本章では，浮遊物に微量含まれる低級脂肪酸と， 浮遊物の主成分である高級脂肪酸のどちらの影響が大きいかを明ら かにすることを目的として，浸漬液に低濃度の低級脂肪酸と高濃度 の高級脂肪酸の試薬を用いて, ライニング材の浸漬試験を行った。

（2）ライニング材試験片

ライニング材は, 前章と同じく日本下水道事業団の規格 $\mathrm{D}$ 種に適 合した汎用的なエポキシ樹脂系ライニング材を成型して $20{ }^{\circ} \mathrm{C} 60 \%$ の環境下で 1 週間養生したものを用いた。試験片は, $60 \times 25 \times 1.5 \mathrm{~mm}$ の短冊状とした。

\section{（3）浸漬液}

浸漬液を Table4 に示寸。低級脂肪酸は，4 章の分析結果から $\mathrm{SC}$, OB ともに含有量の多かった 3 種を, 浮遊物中有機酸総量 $0.1 \mathrm{wt} \%$ の 10 倍の $1 \mathrm{wt} \%$ の水溶液として調製したものを浸漬液とした。高級脂 肪酸は， 5 章の分析結果から $\mathrm{SC}, \mathrm{OB}$ の主成分として同定された 5 種を浸漬液とした。 2 章の調查よりビルピット中の浮遊物は, 排水 中に浮遊し喫水面付近でライニング材と直接接触していたことから, 鹿一級もしくは特級試薬を濃度調整せずそのままの形で用いた。

ビルピット内の排水・浮遊物の温度は, ビルピットと㕌房施設等 からの距離や排水量・頻度等によって決まり，特に距離が近い場合 には，㕌房から沸騰した水が流れ込む場合がある。高級脂肪酸のう ち C12，C14，C16，C18 は，融点がそれぞれ 45，53.8，64，70두 あり，常温で固体であるが，高温の排水が流れ込むビルピットにお いては液体でライニング材に作用寸る。そのため, ビルピットに流 れ込む可能性があり，浮遊物に含まれる高級脂肪酸が液体となる温 度として $75^{\circ} \mathrm{C}$ を浸漬液の温度に設定した。

\section{（4）浸漬試験}

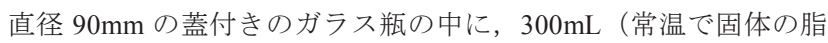
肪酸は $250 \mathrm{~g}$ ）の浸漬液を入れ，試験片 1 片の全部が埋まるように浸 漬した。浸漬中は容器を湯せんし一定温度 $75^{\circ} \mathrm{C}$ に保った。 $75^{\circ} \mathrm{C}$ にお いて, 全ての高級脂肪酸は液体となっていた。浸漬時間 $15 \mathrm{~min} ., 1 \mathrm{~h}$, 1 日, 4 日, 7 日のタイミングで試験片を取り出し, 重量測定と外観 観察を行い評価した。重量測定は, 試験片を純水で洗浄して付着物 を除去し, 清浄なウエスで拭き取り後に行った。初期重量に対する 変化量を初期重量で除し重量変化率を求めた。

Table4 Immersion liquid

\begin{tabular}{|c|c|c|c|}
\hline Group & Symbol & Acid & Concentration \\
\hline \multirow{3}{*}{$\begin{array}{c}\text { Short-chain } \\
\text { Fatty acid }\end{array}$} & C3 & Propionic acid & \multirow{3}{*}{$\begin{array}{c}1 \mathrm{wt} \% \\
\left(\begin{array}{c}\text { aqueous } \\
\text { solution }\end{array}\right)\end{array}$} \\
\hline & $\mathrm{C} 4$ & n-Butyric acid & \\
\hline & $\mathrm{C} 5$ & n-Valeric acid & \\
\hline \multirow{5}{*}{$\begin{array}{l}\text { Long-chain } \\
\text { Fatty acid }\end{array}$} & C12 & Lauric acid & \multirow{5}{*}{$\begin{array}{l}\doteqdot 100 \mathrm{wt} \% \\
\text { (reagent) }\end{array}$} \\
\hline & $\mathrm{C} 14$ & Myristic acid & \\
\hline & $\mathrm{C} 16$ & Palmitic acid & \\
\hline & $\mathrm{C} 18$ & Stearic acid & \\
\hline & C18:1 & Oleic acid & \\
\hline
\end{tabular}

\section{2 試験結果}

浸漬試験結果を Fig. 7 に示寸。低級脂肪酸の $1 \mathrm{wt} \%$ 水溶液に浸漬し 
た試験片（C3， C4， C5）は， 7 日間の浸漬により 5～15\%ほどの 重量増加が見られた。この 3 種類の酸の比較では, 7 日間の浸漬に よる重量の増加量は C5 > C4 > C3 の順であった。C5 7 日間浸漬 した試験片の様子をPhoto5 に示す。

高級脂肪酸試薬に浸漬した試験片（C12， C14， C16， C18， C18:1）は，いずれの試験片も浸漬開始から $15 \mathrm{~min}$. で $10 \%$ 程度の重 量増加を起こし, 膨潤軟化して試験片端部に反りが見られた。端部 の反りの様子は， 2 章の現地調査においてめくれあがっていたライ ニング材や， 6 章の浮遊物と接触させたライニング材試験片と類似 した様子であった。浸漬から 1 日で $100 \%$ 以上重量が増加し，4７ 日で試験片にクラックを生じて形状が崩壊し, 重量測定が不可能と なった。試験片の形状が保たれていた 1 日時点における重量の増加 量は $\mathrm{C} 12>\mathrm{C} 14>\mathrm{C} 18: 1 \fallingdotseq \mathrm{C} 16>\mathrm{C} 18$ の順であった。C16に $15 \mathrm{~min}$. 浸 漬した試験片の様子をPhoto6 に示す。

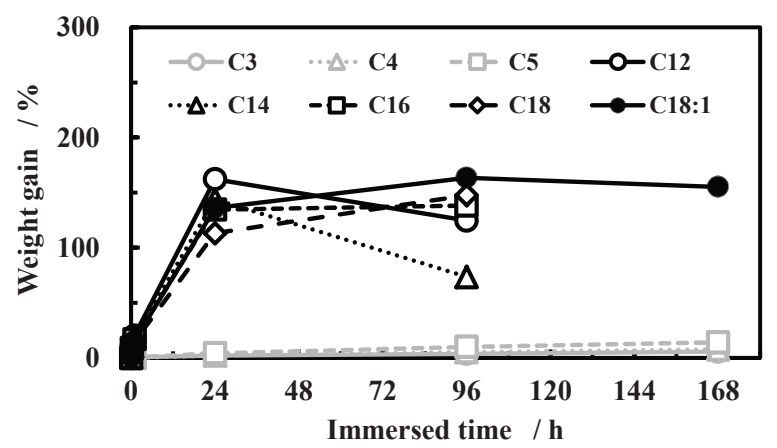

Fig.7 Weight gain of lining material

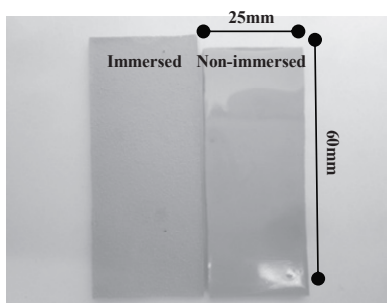

Photo5 Test piece immersed in C5 (7days, $\left.75 \mathrm{C}^{\circ}\right)$

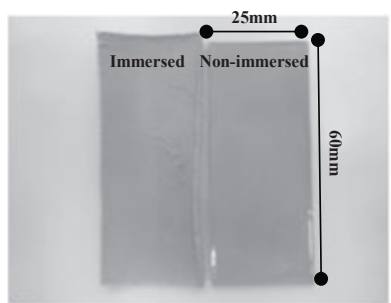

Photo6 Test piece Immersed in $\mathrm{C} 16\left(15 \mathrm{~min} ., \mathrm{CC}^{\circ}\right)$

\section{3 考察}

2 章のビルピット内の調查では, ビルピット内の浮遊物は排水と 分離して喫水面付近でライニング材に接触していた。低級脂肪酸は 水溶性, 高級脂肪酸は非水溶性であり, 浮遊物中の低級脂肪酸は, 浮遊物中の水分に一部溶け込んで水溶液としてライニング材に接触 し, 非水溶性の高級脂肪酸は, 固体または液体で単体としてライニ ング材に接触していると考えられる。一方，本章では，浮遊物に含 まれる総量の 10 倍に相当する濃度 $(1 \%)$ の低級脂肪酸水溶液と $100 \%$ の高級脂肪酸に同条件下でライニング材を浸漬させたところ, 高級脂肪酸への浸漬の方が，ライニング材を著しく劣化させる結果 となった。以上より, $75^{\circ} \mathrm{C}$ の温度条件下においてビルピット内のラ イニング材を劣化させるのは, ビルピット内において相対的に存在 量が多く, 非水溶性で濃度が高い状態でライニング材に接触し得る $\mathrm{SC}$ や OB 中の高級脂肪酸であると考えられる。また, 排水の流れに
おいて, ビルピットに流入する前の暦房排水グリーストラップ中の $\mathrm{OB}$ と, ビルピットから流れ出た後の都市下水処理場の流入井の $\mathrm{OB}$ の構成成分を分析報告した既往研究 ${ }^{12}$ においても, OB の主成分と して高級脂肪酸が含まれることが報告されていることから，今回調 查対象とした建物 A, B 以外のビルピットにおいても同様の機構で ライニング材の劣化が起こり得るものと推察される。

しかしながら，本章の浸漬試験は，ビルピットと嶎房が比較的近 い場合を想定した $75^{\circ} \mathrm{C}$ の温度条件下で実施されており実測に基づ いた温度条件は踏まえられていないこと，低級脂肪酸の水溶液と高 級脂肪酸液体の温度上昇によるライニング材劣化への加速度合いの 違いが考慮されていないこと, 今回試験に用いた高級脂肪酸のうち, 常温においてはオレイン酸 (C18:1) のみが液体状であり, ライニン グ材中への浸透に大きく影響を及ぼすと考えられる固体と液体の分 子の流動性の差異が考慮されていないこと等から，今後さらなる検 討が必要である。

\section{8.まとめ}

ビルピットから採取した排水・浮遊物の成分分析により，ビルピ ット内における脂肪酸の存在状況を把握し, その存在状況を踏まえ た上で排水・浮遊物ならびに低級脂肪酸・高級脂肪酸を使用したラ イニング材の浸漬試験を行い, ビルピット内のエポキシ樹脂製ライ ニング材の劣化機構について考察を加え, 以下のことがわかった。

（1）ビルピット内の排水は褐色で有機物量が多く， $0.01 \%$ 程度の低 級脂肪酸を含んでいる

（2）ビルピット内の排水には固形状の浮遊物が浮かんでおり, 曝気 装置がない場合には泥状で存在し（SC，スカム），曝気装置が ある場合には球状で存在する（OB，オイルボール）

（3） SC と OB の主成分は油が加水分解して生成したパルミチン酸, ステアリン酸，オレイン酸等の高級脂肪酸であり， $0.1 \%$ 程度の 低級脂肪酸も含む

（4）汎用的なエポキシ樹脂製ライニング材は，排水に浸漬させても 顕著な重量増加は見られないが, $\mathrm{SC}$ と OB に接触させると著し い重量増加や変色・変形を伴う劣化を起こす

（5）汎用的なエポキシ樹脂製ライニング材は， $75^{\circ} \mathrm{C} の$ 条件において は，1\%の低級脂肪酸水溶液に比べて $100 \%$ の高級脂肪酸への浸 漬によって, 著しい重量増加を伴う劣化を起こす

（6）ビルピット内の脂肪酸の存在状況と, ライニング材の浸漬試験 結果から, $75^{\circ} \mathrm{C}$ 温度条件下におけるビルピット内のライニン グ材の劣化要因は，浮遊物中の主成分である高級脂肪酸との接 触である可能性が高い

本研究の試薬による浸漬試験は，ビルピット内の実測に基づく温 度条件が踏まえられていないこと，ライニング材中への浸透に大き く影響を及ぼすと考えられる固体/液体の分子の流動性の違い等が 考慮されていないことから，今後さらなる検討が必要である。

\section{謝辞}

本研究の遂行にあたり，昭和電工株式会社 村瀬典子氏，昭和電工 建材株式会社 若林康人氏, 野口隆志氏には, サンプルの提供と分析 方法等に関する貴重なアドバイスを頂きました。ここに深く謝意を 表します。 


\section{参考文献}

1）長谷川完，吉田真悟，高橋拡，鈴木貴大，若林康人，野口隆志：ビルピ ット用ライニング材の厨房排水による劣化機構に関する研究 その 1 研 究概要と排水成分分析, 日本建築学会大会学術講演梗概集 A-1, pp.1269 1270, 2014.9

2）吉田真悟，長谷川完，鈴木貴大，高橋拡：ビルピット用ライニング材の 厨房排水による劣化機構に関寸る研究 その 2 喫水面浮遊物の主成分分 析, 日本建築学会大会学術講演梗概集 A-1, pp.1271 1272, 2014.9

3）高橋拡, 長谷川完, 吉田真悟, 鈴木貴大, 若林康人, 野口隆志 : ビルピ ット用ライニング材の厨房排水による劣化機構に関する研究 その 3 有 機酸浸漬試験によるライニング材の評価, 日本建築学会大会学術講演梗概 集 A-1, pp.1273 1274, 2014.9

4) 平野竜行, 村上信直, 板倉静雄, 竹久英治, 谷岡由男: 腐食環境抑制型 防食手法(アクティブライニング)に関する研究, 日本建築学会大会学術講演 梗概集 D-1，pp.575〜 576，1999.9

5）佐々木晴夫：厨房排水槽の防食技術， BE 建築設備， Vol.52 No.12, pp.31-37, 2001.12

6）三品文雄編著：さらに詳しい下水道腐食対策講座 基礎から応用まで，環 境新聞社，2003
7）地方共同法人 日本下水道事業団：下水道コンクリート構造物の腐食抑制 技術及び防食技術マニュアル，一般社団法人 下水道事業支援センター, 2012

8）系平敏也，渡部康夫，足立伸幸：污水中の有機脂肪酸による防食塗料一 の影響に関寸る研究, 日本建築学会大会学術講演梗概集 A-1, pp.1003-1004, 2013.8

9） 久保内昌敏, 平元伸一郎, 鄭盛吉, 仙北谷英貴, 津田健 : 有機酸水溶液 環境下におけるアミン硬化エポキシ樹脂の劣化挙動および環境液の侵入挙 動，材料の科学と工学， Vol.42 No.4， pp.211〜217， 2005.8

10）渡部康夫，系平敏也，足立伸幸：厨房排水中の有機脂肪酸による防食塗 料への影響に関する研究，日本建築学会大会学術講演梗概集 A-1, pp.1111 1112， 2014.9

11）高地進，小南和也，小早川香，川谷翔二，岡崎隆：グリース阻集器の流 出管径と阻集性能についての検討, 日本建築学会大会学術講演梗概集 D-1, pp.631-632， 2013.8

12）嶋野雄大，小林敬之，局俊明：食堂排水および下水中のオイルボール構 成成分と流入水中成分の関係，用水と廃水，Vol.56 No.5， pp.358-363， 2014.5 


\title{
IDENTIFICATION OF DEGRADATION FACTORS OF LINING MATERIAL BY COMPONENT ANALYSIS OF SUBSTANCES IN PITS AND IMMERSION EXPERIMENT
}

The mechanism of degradation due to kitchen drainage of lining material for building pits Part1

\author{
Shingo YOSHIDA*, Tamotsu HASEGAWA** and Hiromu TAKAHASHI*** \\ * Associate Chief Researcher, Takenaka Research \& Development Institute, M. Eng. \\ ** Chief Researcher, Takenaka Research \& Development Institute \\ *** Chief Researcher, Takenaka Research \& Development Institute, M. Eng.
}

There are many cases where restaurant areas equipped with kitchen facilities are created in buildings such as office buildings, shopping malls, or hotels. A large amount of organic compounds from cooking oils and food waste is contained in the kitchen drainage water. Drainage water is impounded in a pit located in a basement before being discharged into the sewers. Epoxy resin is used as a lining material for pits in Japan because of its high chemical resistance. However, cases of remarkable degradation in the lining material (epoxy resin) were seen in building pits. The purpose of this paper is to identify the factors in the degradation of lining materials.

Drainage water and floating substances were sampled from two building pits. The floating substances from building A are called "SC" for being in a scum-like form. The floating substance from building B is called "OB" for being orbicular. A water analysis was conducted on the drainage water samples (Table1). Both samples contained a level above the Japanese effluent standards of organic substances. An organic acid analysis was conducted on the drainage water, SC, and OB (Table2). The total amount of short-chain fatty acids was about $100 \mu \mathrm{g} / \mathrm{mL}(\doteqdot 0.01 \%)$ at the most in the drainage water and about $1000 \mathrm{\mu g} / \mathrm{g}(=0.1 \%)$ at the most in the floating substances. A thermal gravity analysis (TGA) (Fig.1) and a pyrolysis-gas chromatography/mass spectrometry (pyGC/MS) analysis (Fig.2-5, Table3) were conducted on the SC and $\mathrm{OB}$. It was clear from the results that the major component of SC and $\mathrm{OB}$ were long-chain fatty acids, particularly palmitic acid (C16), stearic acid (C18), and oleic acid (C18:1).

Test pieces of epoxy lining material were created and then immersed in the drainage water (DW), SC and OB (Fig.6, Photo1, 2). The test piece immersed in DW did not increase the weight, whereas those immersed in SC and OB remarkably increased the weight. Remarkable, obvious changes and degradation occurred in the test pieces immersed in SC and OB (Photo4). Test pieces were immersed in a 1\% aqueous solution of short-chain fatty acids and in a long-chain fatty acid reagent at $75^{\circ} \mathrm{C}$ (Table4, Fig.7). The long-chain fatty acid reagents were liquid form at $75^{\circ} \mathrm{C}$. Those immersed in the 1\%aqueous solution of short-chain fatty acids did not increase the weight, whereas those in the long-chain fatty acid reagent remarkably increased the weight in a short period. The test pieces immersed in the long-chain fatty acid reagent were obviously expanded(Photo6).

From the results above, it should be concluded that the factors causing the degradation of epoxy resin as a lining material in a pit were long-chain fatty acids contained in floating substances. 